\title{
Bringing Together Feminism and Socialism in the First International
}

\author{
Four Examples
}

Antje Schrupp

The International Working Men's Association (IMWA) was a predominantly, if not only, male organization, at least as far as its leading members or its international congresses were concerned. When Karl Marx suggested Engels' partner Lizzy Burns to join the association, he explicitly asserted that "Ladies are admitted"1 - so female membership was obviously not to be taken for granted. And indeed, only a few women actually did play an active role in the International ${ }^{2}$, and only male delegates participated at all seven international congresses and conferences. ${ }^{3}$ This was not as self-evident as it might seem. After all, women had been participating actively and in large numbers in earlier so called "utopian" socialist movements. The second half of the nineteenth century saw the emerging of various feminist movements, focusing mainly on the promotion of women's access to the labour market. Other international organizations of the time, such as the League of Peace and Freedom, had numerous female members as well as women speakers at their congresses.

1 Marx to Engels, 25 January 1865, in Karl Marx und Friedrich Engels, Briefwechsel Vol III (Berlin, 1950), p. 259.

2 Besides the four activists in this article, Harriet Law, who was a member of the General Council from June 1867 to August 1869 and regularly participated in its meetings, should also be mentioned. See: Documents of the First International. Minutes of the General Council, 4 vol., (London, 1964), Vol. 2, p. 110, Vol. 3, pp. 72f, 90,124f, 247; see also Henry Collins and Chimen Abramsky, Karl Marx and the British Labour Movement. Years of the First International (London, 1965), pp. 110, 15of, 241.

3 Women did participate in local IWMA activities; for instance there was a very active Women's Section in Geneva; see Antje Schrupp, "Die Genfer Frauensektion der Ersten Internationale", MEGA-Studien (Berlin, 1999), pp. 107-125. Sometimes women's sections created irritations, especially when they were formed in industries with male and female workers alike, because there could be conflicts of interests. This problem was discussed at the London Conference of 1871 and led to the decision - on the proposition of Marx - that women were allowed to form their own sections if they wanted to; see Jacques Freymond, La Première Internationale. Recueils et documents 4 vol. (Genève, 1962-1971), vol. 2, p. 167, footnote 11. 
However, the First International was not only male-dominated, it even showed an anti-feminist image, at least in its first years. The Proudhonist leaders in France were strongly opposed to paid work for women and even any female activity outside the household, which is quite clearly in opposition to contemporary feminism. This position was at least partly written into the resolutions which were officially adopted by the first two Congresses of the International.

In Genève (1866) the delegates discussed for several hours the prohibition of female paid work. The discussion started with a paper of the General Council promoting an eight-hours-workday, that, among many other things, suggested prohibiting women's work at night, in circumstances that could be dangerous for their bodies or threaten their virtue. The majority of French delegates however wanted to forbid female work outside the household altogether, a position the British delegates in turn qualified as "crazy" under the given circumstances of industrialization. ${ }^{4}$ Only two delegates, Eugène Varlin and Antoine Bourdon, argued in favor of female work on equal terms, suggesting to improve working conditions for everybody - a position, that was also held by the great majority of contemporary feminists. ${ }^{5}$ But in their voting the delegates of the IWA approved both the papers of the General Council and the French majority (strangely, as they contradicted each other) but clearly dismissed the proposition of Varlin and Bourdon.

To further discuss the "women's question" a commission was founded to prepare a paper for the next annual congress in Lausanne (1867). And again a vast majority of delegates voted against paid work for women, supporting a speech given by Belgian Cesar de Paepe who stated, that industrial work for women was "unnormal and against nature". ${ }^{6}$ So not only our emancipated perspective

4 The discussions are documented in Freymond, La première Internationale, vol. 1, pp. 31-50.

5 Especially British feminists advocated against laws that prohibited female work in order to "protect" the female body, because that made access to the labour market more difficult. See for instance Barbara Bodichon, Women and Work (London 1859); Harriet Martineau, Illustrations of Political Economy (London, 1859); Bessie R. Parks, Essays on Women's Work (London, 1865). In 1858 some of them founded the "Langham Place Circle" which advocated women's work on equal terms and founded enterprises to provide paid work for women; see Diane M.C. Worzala, The Langham Place Circle: The Beginnings of the Organized Women's Movement in England (Ph.D., University of Michigan, 1982).

6 Freymond, La première Internationale, vol. 1, p. 215. De Paepe added that the question was discussed controversially in the Belgian branch, and also read a minority paper in favour of women's work signed by Paul Robin, Eugène Hins and P. Eslens who were not present at the Congress. 
from the 21st century sees the organization as anti-feminist. As a result of their position, most women activists of the time also did. ${ }^{7}$

Despite this, some female socialists decided to take an active role in the International. How did they combine both feminism and socialism in their political ideas? What strategies did they use to bring together two political goals that in their time were mainly considered as being opposed to each other?

In my dissertation ${ }^{8}$, published fifteen years ago, I discuss the political ideas of four women activists of First International:

- Virginie Barbet, one of the leaders of the International in Lyon and a member of the Bakunist Alliance of Socialist Democracy;

- Elisabeth Dmitrieff, one of the leaders of the Russian section in Geneva and a co-founder of the Union de Femmes during the Paris Commune;

- André Léo, Paris-located author and an advocate of women's rights, supporter and critic of the Commune and later a leading figure in the protests against the "authoritarian" way of the General Council;

- Victoria Woodhull, a controversial leader of the American suffrage movement, who founded the first English-speaking sections in New York, but was expelled from the International at the Hague-Congress of 1872.

I had hoped my research would be somewhat outdated by now. However, it seems that still little attention is being paid to gender issues related to the First International or to its female activists. And this is something which I myself can partly understand. I myself struggled with what I had found out about my protagonists.

When I started my research, I somehow wanted to find a "female" voice in this all-male labour movement. But even though those four women were highly involved in the movement, I could not really identify what they stood for. What were their opinions on the "big questions" being discussed under the roof of the First International? What did they think for instance, about the

7 Swiss Feminist Marie Goegg for instance criticized the IWMA explicitly for not collaborating with the Women's Movement in a speech she gave in September 1868 at the annual Congress of the Peace and Freedom League in Bern; see Berta Rahm, Marie Goegg (Schaffhausen, 1993), pp 95f. On the other hand French Internationalists were even proud of being opponents to those "partisans de la prétendue emancipation de la femme", see E[rnest] Fribourg, L'Association internationale des travailleurs (Paris, 1871), p. 43.

8 Antje Schrupp, Nicht Marxistin und auch nicht Anarchistin. Frauen in der Ersten Internationale (Königstein 1999). 
common property of the land, the private property of the means of production, the founding of working-class parties?

Compared to the "great" polemic texts of the male internationalists, those women seemed somewhat inconsistent, even weak in their statements. They didn't really fit into the lines of interpretations that are usually used to classify the International's protagonists, such as Marxists or anarchists for instance. So, perhaps that was the reason why researchers of the International didn't find them so interesting.

By the way: the same was true for feminist researchers on women's history. They also showed no interest in these women as they did not represent strong voices for classical women's rights arguments either - such as the right to vote for instance.

The only interesting thing seemed to be the fact itself: that they were members of the International despite being feminists.

Only when I was ready to admit that - and it took me a while - I realized that this was not a banal observation at all.

Why had they, being feminists, become members of the International in the first place?

Victoria Woodhull (1838-1927) for instance. ${ }^{9}$ She is one of the few voices of the real "Lumpenproletariat" in the history of socialism: Not only is her background non-bourgeois, she also is non-proletarian since neither she nor her parents held any "respectable" jobs. ${ }^{10}$ Born the seventh child to a family of petty thieves and con artists, she had earned her living for many years as a spiritual advisor and clairvoyant for both sexes but particularly for women. By doing so she became acquainted with the most basic life problems of the lower classes - poverty, childbearing, exploitation, early death, rape and so on.

Her shift into politics became possible when in 1865 she fell in love with one of her clients, James Blood, a soldier that had been traumatized in the Us civil war. He was an active member of the reform movements of those days,

For the full biography of Victoria Woodhull see Antje Schrupp, Das Aufsehen erregende Leben der Victoria Woodhull (Königstein, 2002). See also Lois B. Underhill, The Woman Who Ran for President (New York, 1995); Mary Gabriel, Notorious Victoria. The Life of Victoria Woodhull, Uncensored (Chapel Hill, 1998); Barbara Goldsmith, Other Powers. The Age of Suffrage, Spiritualism, and the Scandalous Victoria Woodhull (New York, 1998); Amanda Frisken, Victoria Woodhull's Sexual Revolution (Philadelphia, 2004).

10 She puts her political theories in numerous books and speeches, e.g. Victoria Woodhull, The Origin, Tendencies and Principles of Government (New York, 1871); Victoria Woodhull, A Speech on the Principles of Social Freedom (London, 1984). Other important texts in Madeleine B. Stern, The Victoria Woodhull Reader (Weston, Mass., 1974). 
mainly socialism and abolitionism. So, he helped Woodhull to bring into the political arena her experiences and political ideas which she had formed from her experiences.

A few years after, she made a fortune by giving advice to multi-millionaire Cornelius Vanderbilt. She probably had insider information from some of her friends who worked as prostitutes for wealthy clients. She became really rich and with her wealth she did not only open the first female broker office at Wall Street but also her own weekly newspaper, the Woodhull and Claflin's Weekly.

Victoria Woodhull also paved her way into the organized feminist movements of her days. Those mostly middle-class feminists, however, did not receive her with arms wide open. They strongly doubted her "respectability", and rightly so. Victoria Woodhull openly advocated free love, the abolition of marriage laws, and in no way did she confine her activism to suffrage alone. But when she managed to give a speech on defending female suffrage on 11 January 1871 in front of the Judiciary Committee of the Senate and Congress in Washington, the suffrage movement could no longer ignore her and instead made her its leader and spokeswoman.

So, why did this woman join the First International? Why did she have the Communist Manifesto translated into English and published it in her newspaper, the Woodhull and Claflin's Weekly? ${ }^{11}$ Why did she co-found sections of the International in New York and fight conflicts with the "Marxist" German section? Why did she organize a demonstration in honour of the Paris Commune? All of this only got her into further trouble with the women's movement, where she already had problems defending her leadership!

We could ask similar questions about Virginie Barbet. Unfortunately, I have not been able to find out a lot about her as a person - unlike the scandalous Victoria Woodhull, she didn't make the newspaper headlines of her time. I don't even know her date of birth.

But she must have been a rather important figure in the Lyon International. I stumbled upon her when I found some inconsistencies in the protocols of the Alliance of Socialist Democracy which led to the conclusion that an important yet unsigned article in the journal Egalité (advocating the abolition

11 The Weekly reported on feminist, socialist and spiritualist subjects. Its first number appeared on 14 May 1870 , the last in early 1876 , although at the end numbers came out only randomly. The translation of the Communist Manifesto was printed on 30 December 1871, and there were other contributions of European IWMA members such as Robert Applegarth. In September 1871, Marx wrote to the editors sending an article of his daughter Jenny which they printed: Karl Marx, Friedrich Engels, Gesamtausgabe (Berlin, 1978), XXII, pp. $469-476$. 
of inheritance laws) almost certainly had been written by her, and not by Bakunin to whom it is usually contributed..$^{2}$

I became interested in who this woman was and how she had become involved. She probably first met Bakunin and his allies at the 1868 congress of the League of Peace and Freedom in Bern, where she gave a speech as the representative of the "Social Democrat Women of Lyon", which is how she introduced herself.

It was at this congress that Bakunin and his friends split away from the Peace and Freedom League and founded their own organization, the Alliance, which would later join the First International. Barbet's name is not listed among the initial founders of the Alliance. But one year later, in June 1869, she would be listed as a "founding member of Lyon". She published some interesting texts, on atheism for instance, or defending the International against Mazzini. ${ }^{13}$ And she helped organize a big strike of mostly female textile workers in the summer of 1869 in Lyon that brought a lot of new members to the International - even though their demands were only half-heartedly supported. ${ }^{14}$

Prior to her involvement with the International, Virginie Barbet too had already been involved with the feminist movement. Together with Marie Richard - the mother of Albert Richard - she was a founding member of a feminist group in Lyon that advocated a rather "egalitarian" form of feminism and the abolition of all gender differences. ${ }^{15}$ It is the similar kind of genderegalitarianism which can be found in Bakunin's Alliance programme.

Egalitarianism, we must know, was not mainstream in French feminism at the time. There was still a rather big impact of Saint-Simonian feminism that had prevailed in the first half of the century. The Saint Simonians tried to draw upon gender differences, for instance, they formed separate groups and structures for men and women and had a formal 5o-per-cent quote for both genders in their leadership. Their argument was that because women were different from men they should have a voice in the decision-making process.

12 «De l'hérédité » in Egalité, Journal de l'Association internationale des travailleurs de la Suisse romande, Genève (1868-1872), 12 June 1869. For details on this conclusion, see Antje Schrupp, Nicht Marxistin und auch nicht Anarchistin, pp. 5 off.

13 Virginie Barbet, Déisme et Athéisme. Profession de foi d'une libre-penseuse (Lyon, 1869); Virginie Barbet, Réponse d'un membre de l'Internationale à Mazzini (Lyon, 1871).

14 See Claire Auzias and Annik Houel, La grève des ovalistes, Lyon, Juin-Juillet 1869 (Paris, 1982). For Barbet's role see Antje Schrupp, Virginie Barbet, Une Lyonnaise dans l'Internationale (Lyon, 2009), pp. 39 ff.

15 The «Manifeste des femmes lyonnaises adhérentes à l'Internationale » is documented in Oscar Testut, L'Internationale et le Jacobinisme (Paris, 1872), I, pp. 277-279. 
But due to the then upcoming anti-feminist ideology of "separate spheres", which was driven forward by many male thinkers, particularly in France, focusing on gender differences became more and more dangerous for feminists. So, some of them shifted their line of arguments to a more egalitarian approach, although Saint-Simonian convictions still remained strong.

Another French feminist who represents this shift, while being far better known than Barbet, was André Léo (1824-190o). ${ }^{16}$ By the time she joined the International in the late 1860's, she was a well-known author of novels with strong female characters. She had also been involved in various feminist organizations and activities prior to joining the International. For instance she was one of the principal founders of the Société pour la Revendication des Droits de la Femme. In 1869 she published her theoretical book Les femmes et les moeurs.

And like Victoria Woodhull, her involvement with the International got her into conflict with her more "bourgeois" feminist allies. Actively supporting the Paris Commune isolated André Léo from the French women's rights movement. But she did not evade conflict with either side. She criticized the feminists for not supporting social issues, but also those socialists that advocated militant and violent concepts of revolution. She publicly criticized the editors of L'Egalité, the journal of the Roman Swiss branches of the International, and later the Blanquists in the Commune. In opposition to them, she pointed out the necessity of instruction and deliberation, and insisted that the end does not justify the means. ${ }^{17}$

And last but not least there was Elisabeth Dmitrieff (1851-1910), a young Russian, who played a leading role in the Russian Section in Geneva. ${ }^{18}$ She was only nineteen years old when she went to London to meet Karl Marx personally and then moved on to Paris where she founded maybe the largest women's organization of the Commune.

She came from an entirely different background compared to the other three. Having been raised in an aristocratic family (although an illegitimate child), she married a male ally so she could leave Russia. She had been influenced by "Nihilist" feminism which was very different from Western feminism, mostly because the young Russians had never experienced the strong regiment of

16 See Alain Dalotel, André Léo (1824-19oo), La Junon de la Commune (Paris, 2004); see also Frédéric Chauvaud et al., Les vies d'André Léo. Romancière, féministe et communarde (Rennes, 2015).

17 For the role of women in the Paris Commune, see especially Edith Thomas, Les Pétroleuses (Paris, 1963).

18 See Sylvie Braibant, Elisabeth Dmitrieff. Aristocrate et pétroleuse (Paris, 1993). 
the "separate spheres" ideology. In non-industrialized Russia the difference of classes still outweighed the difference of sexes by far. So, the young, revolutionary, "emancipated" women with aristocratic self-esteem did not linger on what women could not do. They were convinced that women could do everything they wanted, if they only had the determination and willingness to do so. In that, by the way, Dmitrieff was similar to Victoria Woodhull who due to her lowerclass-background was not held back by bourgeois concepts of womanhood drafting women as weak and in need of male protection - either.

It is not hard to imagine, that some "clash of cultures" must have taken place in Paris, when this young, self-assured woman started to organize the "Union des Femmes" without consulting the opinions of the older feminists. Unfortunately, we have only some vague hints as to the nature and issues of those disputes.

Dmitrieff was not at all isolated in Paris. She not only had support from the Marxists in the International but also was an old friend and admirer of Anna Jaclard (1843-1887), whom she had already got to know back in Russia. It was together with her and Anna's sister Sofia Kowalewski (1850-1891), who later became a famous mathematician, that Dmitrieff had left Russia. And back in Geneva she had already established a friendship with Benoit Malon, who by now had become the lover of André Léo.

So, there were many intersections between the feminist protagonists during the Commune, but there were also differences. For instance, why did neither André Léo nor Anna Jaclard join Dmitrieff's Union? I am convinced that deeper research, particularly on those differences would be enlightening, but this has yet to be done.

So, what can we make of this examples? What is the contribution of these four women to the history of socialism, to the history of the First International?

I would like to put forward an interpretation that takes into consideration the difficult relationship between socialism and feminism at the time.

As I've already pointed out, feminists were somewhat forced to shift their arguments from focusing on gender differences to focusing on gender equality. And maybe some of them moved one step further and decided to not only shift their arguments but also their actions.

They kind of infiltrated male political organizations in order to change their point of view on women, and to keep feminism "in", not by arguing, but by simply being there. Perhaps this was the only way to handle the serious problem of revolutionary movements of the time: the drifting apart of feminism and socialism.

The early socialist movements in the first half of the nineteenth century still had a broad agenda, including not only economics and politics but also 
culture and explicitly the relationships between women and men and children and new forms of family and community-building. On this basis, feminism and socialism weren't considered as separate movements. After all, workers and women alike were being excluded from the rights of bourgeois men and suffered from the material consequences of a concept that defined "equality" as only a formal right.

But in the $185^{\circ}$ 's, the issues and concerns of the feminist and socialist movements drifted further and further apart.

For the women's movement it was no longer about change in society, but equal rights with men: access to the labour market, reform of marriage laws, and the right to vote. And for the labour movement it was no longer new forms of living, working, and loving, but higher wages, political parties and other means to increase the political influence of workers.

So, both movements were losing the broader cultural perspective, and consequently, feminism and socialism lost their common ground. In the end, they often found themselves on opposite sides of the fence in defending the interests of women or those of male workers. Feminist movements became antisocialist, socialist movements became anti-feminist. ${ }^{19}$

A woman with a feminist agenda that joined a male-dominated labour organization made it out of that stalemate. She would criticize and contest that stalemate, not by writing yet another pamphlet or founding yet another party, but proving it wrong in action. She would leave the politics of positions and standpoints and start - or continue - a politics of relations.

Those women joined male spheres not in order to argue about women's rights, but in order to bring their personal difference into play.

I call this "embodiment of politics". Bringing a female body to places, where women are not expected and maybe not even be welcome, creates the necessity of mediations, that otherwise would not take place.

When we now take a fresh look at the texts and actions of those women Internationalists, we have a new perspective. What seemed inconsistent and weak in matters of positions and straight opinions, now becomes reasonable. Those women did not want to carve out differences and standpoints. They wanted to keep social issues connected that in their opinion belonged together - socialism and feminism. They relied on acting in a concrete

19 Only later, starting in the 1880 s, feminist views were integrated into the socialist movements to some degree, thanks to activists like Clara Zetkin, August Bebel, Eleanor Marx or William Morris. But by then, the feminist movement was strictly divided into "socalist" and "bourgeois" branches, which were opposed to each other as much as they were opposed to misogynists in their own ranks. 
contingent situation, and therefore their positions and opinions would adapt to that situation and to the concrete persons involved. They did not act on principles, but on necessities in a given context.

By doing so they also challenged one of the main topoi of the time: that politics meant struggle between opponents and parties. Pointing out contradicting interests was a spreading strategy in labour and feminist movements alike - men against women, labour against capital.

By contesting this topos, the feminist socialists earned themselves the verdict of not being radical enough, and they earned it from their fellow socialists as well as from their fellow feminists.

But it was not a lack of radicalism, but faithfulness to the roots of the social movements, to keep a broader agenda - namely the common good, that included all aspects of life and did not consider some as more important than others. A point of view which, by the time of the International, was discredited as "utopian" in socialist ranks and as "naive" in feminist ones.

That doesn't mean that those feminist socialists ignored or negated the real difficulties or contradictions. There really was antagonism in the interests of women and men or of capital and labour. Trying to negate this on a theoretical level would have truly been utopian or naïve.

But by opting for the politics of personal intermediations, they found another way: going to the places of the others and talk to them. Establishing relationships, staying in contact, instead of deepening the abyss by still one more sharp analysis.

I am inclined to call this the "politics of women" because it is a common experience among women to not rely on a fixed identity. Women have always experienced many changes in their lives, such as name changes when they marry, change of work when they have children and so on. The existence of a woman does not depend on any fixed "identity" but on the relations she is involved in.

And in her writing and speaking she does not aim at finding an identity but at finding intermediations. Intermediations between what she is and wants right now and what the other is and wants; the concrete other that she has to deal with in a given context. That means negotiating, taking into consideration her own wishes and convictions as well as those of the other people involved, not in an abstract and theoretical manner, but concretely, here and now. ${ }^{20}$

At least this is the lesson I have learned from those feminist socialists in First International: that the concrete interactions and relations between activists

20 See also Antje Schrupp, "Politik verkörpern statt Stellung beziehen", in Ina Praetorius (ed.), Sich in Beziehung setzen. Zur Weltsicht der Freiheit in Bezogenheit (Königstein, 2005), pp. $37-48$. 
are the center of politics, and not their fixed pamphlets, the consistency of their theories, or the standpoints they take. It is only in relations with others that we develop political ideas, and as valuable as texts, positions and viewpoints surely are, they are not what really matters in political activism.

And this lesson is, unsurprisingly, still true and relevant for social movements of today.

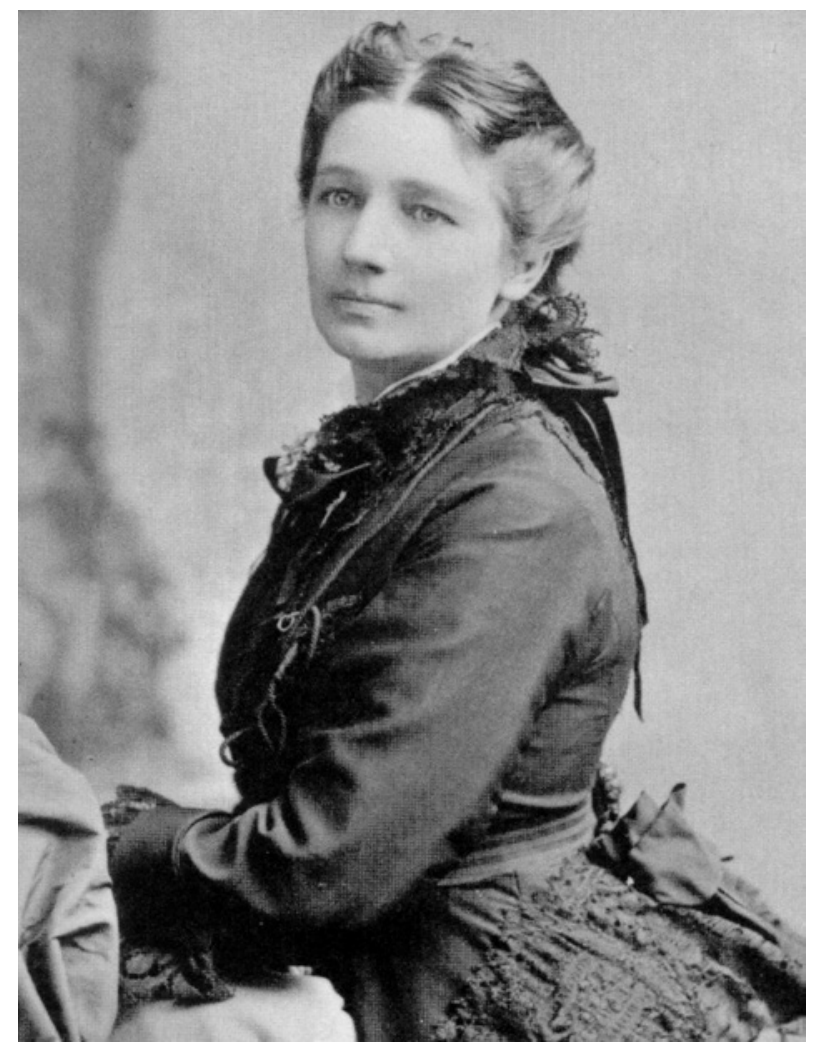

FIGURE 22.1 Victoria Woodhull c. 1869 .

PRIVATE COLLECTION. FOTO BY BRADLEY \& RULOFSON, PUBLIC DOMAIN (FOR COPYRIGHT-DETAILS SEE: HTTPS://COMMONS.WIKIMEDIA.ORG/ WIKI/CATEGORY:VICTORIA_WOODHULL\#/MEDIA/FILE:VICTORIA_C _WOOHULL_BY_BRADLEY_\%26_RULOFSON.PNG). 


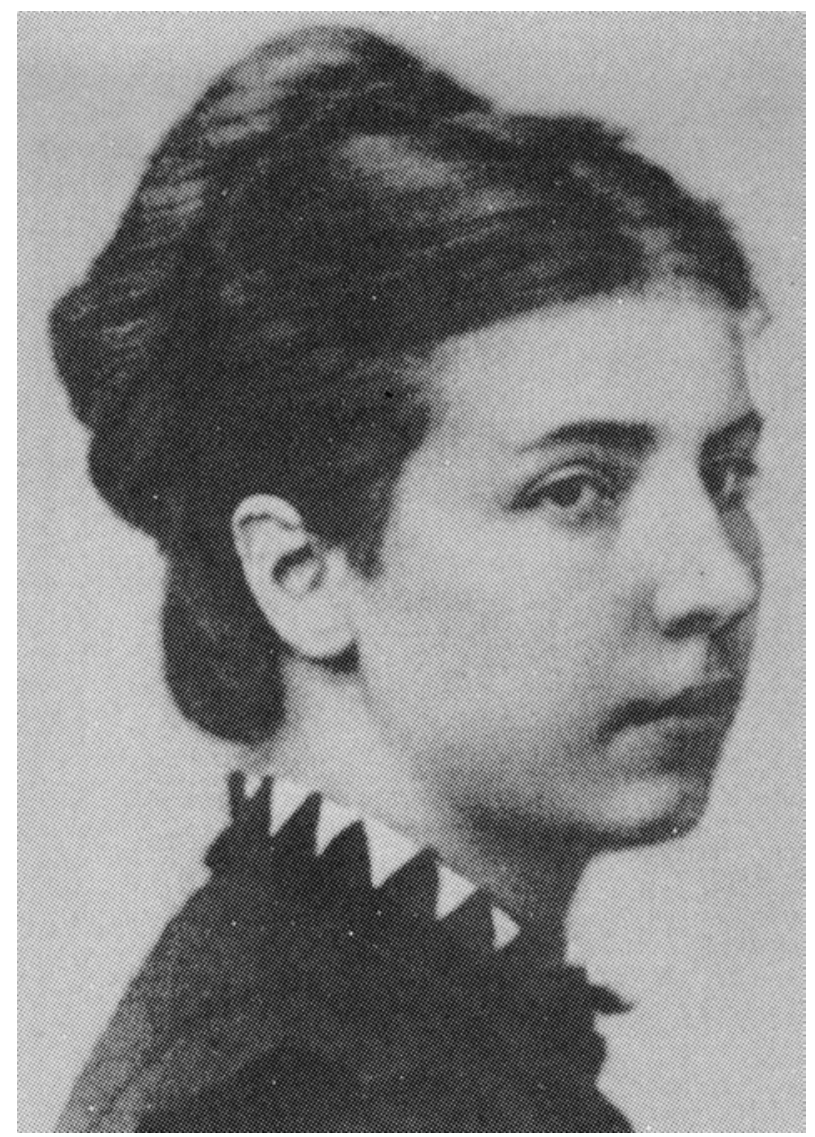

FIGURE 22.2 Elisabeth Dmitrieff. SOURCE: SYLVIE BRAIBANT, ELISABETH DMITRIEFF, BELFOND, 1993. 